\title{
Anopheles darlingi bionomics and transmission of Plasmodium falciparum, Plasmodium vivax and Plasmodium malariae in Amerindian villages of the Upper-Maroni Amazonian forest, French Guiana
}

\author{
Romain Girod $/{ }^{+}$, Pascal Gaborit, Romuald Carinci, Jean Issaly, Florence Fouque \\ Medical Entomology Unit, Institut Pasteur de la Guyane,BP 6010, 97306 Cayenne Cedex, Guyane Française
}

\begin{abstract}
French Guiana is one of the areas in South America most affected by malaria and where the disease has become a serious public health problem. In spite of this situation, little recent entomological data are available from the main localities where the disease occurs, even though they are crucial for development of an effective vector control strategy. A longitudinal entomological survey was carried out from March 2000-February 2002 in three Amerindian villages, namely Twenké, Taluène and Cayodé, located in the Amazonian forest of the Upper-Maroni area, to assess anopheline mosquitoes and malaria transmission dynamics. Anopheles darlingi (Diptera: Culicidae) was the most abundant mosquito species caught during the study. This efficient American malaria vector was active the entire year, but showed an evident peak of abundance during the main rainfall season, from April-June, with an average human biting rate of 255.5 bites per person per night. Parity rates were homogeneous all year, indicating no significant seasonal variability in female survival rates. Estimated vectorial capacity indices were higher during the rainy season, even though the risk of transmission was present throughout the year $(V C I>1)$. A total of $14 \mathrm{An}$. darlingi were found infected with Plasmodium falciparum, Plasmodium vivax or Plasmodium malariae. The annual circumsporozoite indices were $0.15,0.14$ and 0.05 , and the entomological inoculation rates were 22.8, 27.4 and 14.4 infected bites per person per year in Twenké, Taluène and Cayodé, respectively. An. darlingi was endo-exophagic and rather exophilic in these localities. The species was collected throughout the night but was more aggressive between 21:30-03:30 h and after 05:30 h. Parity rates were homogeneous during the entire night. Impregnated hammock and/or bed nets, coupled with the use of mosquito repellents, as well as the early treatment of malarial cases, appear to be the most suitable tools for fighting malaria in these Amerindian villages since the spraying of residual insecticides is inefficient because of vector biology and the housing structure.
\end{abstract}

Key words: Anopheles darlingi - French Guiana - malaria transmission - Maroni River - vector control

French Guiana is one of the areas in South America most affected by malaria, and is also the French overseas province where this disease causes the most serious public health problem (Hommel et al. 1997, Carme $\&$ Venturin 1999). The annual malaria incidence has increased ten-fold during the last 30 years, currently reaching approximately $3 \%$, with $60 \%$ due to Plasmodium falciparum (Carme 2005). Autochtoneous cases are occasionally reported in the coastal area inhabited by $80 \%$ of the population, but the main malaria-endemic areas are located in the inland forested areas and especially along the Oyapock and Maroni rivers (Juminer et al. 1981, Lepelletier et al. 1989).

The Maroni valley extends nearly $500 \mathrm{~km}$ from the Mitaraka Mountains to the Atlantic coast and forms a natural border with Suriname in the Western part of French Guiana. Along the river, a diversified population

Financial support: Direction de la Santé et du Développement Social (DSDS) de la Guyane, French Ministry of Health

+ Corresponding author: rgirod@pasteur-cayenne.fr

Received 13 June 2008

Accepted 19 September 2008 maintains intense exchanges between the French and the Surinamese sides. The three human malaria parasite species found in French Guiana are P. falciparum, Plasmodium vivax, and Plasmodium malariae. P. falciparum is predominant in the Bushinenge populations on the lower and medium parts of the Maroni, whereas both $P$. vivax and $P$. malariae also infect the Amerindian populations of the Upper-Maroni area, where the malaria incidence, which is about 200 per 1000 , is one of the highest in French Guiana. In this Amazonian forested area, malaria transmission is permanent, the endemic situation is stable and the disease primarily affects children (Stroebel et al. 1985, Esterre et al. 1990).

Anopheles darlingi, one of the most common and efficient malaria vectors in the Americas, is widely distributed in French Guiana, where it is considered to be the primary malaria vector because of its anthropophilic behaviour, its natural infectability, its higher density and its sensitivity to P. falciparum (Floch \& Abonnenc 1951, Floch 1955). Other species, such as Anopheles aquasalis, Anopheles braziliensis, Anopheles neivai, Anopheles oswaldoi and Anopheles nuneztovari are also present and might be occasional and local vectors. Even if these species have been incriminated in transmission in other neighbouring countries, their role in malaria transmission in French Guiana has never been proven (Mouchet et al. 1989). 
An. darlingi and malaria transmission dynamics have been assessed during the 80's in Bushinenge Surinamese villages located in the Upper-Maroni area (Hudson 1984, Rozendaal 1987, 1989, 1992). These authors showed that An. darlingi was the most common anopheline mosquito found on human baits at night in or near houses, and they have described seasonal and geographical fluctuations in relation with rainfall and river levels and pointed out that the relative abundance of the vector could not be easily related to the prevalence of human malaria.

Field observations have been made during the 90's in French Bushinenge villages and also in French Amerindian villages upstream of the river, but no data have been published.

Malaria control on the French side of the Upper-Maroni area is based on curative treatment of cases and regular deltamethrin spraying of houses. However, the disease is still endemic in the area, despite of the efforts deployed by the sanitary services for many years. The main limiting factors for successful control are the absence of preventative measures at the individual or community level and the inadequacy of vector control measures which are not adapted to the vector bionomics and socio-cultural habits (Cochet et al. 1996, Raccurt 1997).

Entomological studies are crucial for assessment and improvement of vector control activities. Fluctuations in malaria incidences are not well understood on the French side of the Upper-Maroni area and prediction of vector densities and transmission levels could lead to more effective and less costly operations. For these reasons, a longitudinal survey was carried out, from March 2000 -February 2002, to study malaria vectors and transmission dynamics in three Amerindian villages located on the Amazonian forest of the Upper-Maroni area.

\section{MATERIALS AND METHODS}

Study site - This study was implemented in three Amerindian villages, namely Twenké $\left(3^{\circ} 23^{\prime} \mathrm{N}, 54^{\circ} 03^{\prime} \mathrm{W}\right)$, Taluène $\left(3^{\circ} 22^{\prime} \mathrm{N}, 54^{\circ} 02^{\prime} \mathrm{W}\right)$ and Cayodé $\left(3^{\circ} 23^{\prime} \mathrm{N}\right.$, $53^{\circ} 55^{\prime} \mathrm{W}$ ), located in the Amazonian forest, in the Upper-Maroni basin, about $35 \mathrm{~km}$ south of the main town of Maripasoula. The villages were selected for their relative population stability and easy access: each village, situated about an hour and a half from Maripasoula by boat, was inhabited by around a hundred Amerindians belonging to the Wayanas ethnic group. Twenké and Taluène are two neighbouring hamlets located on the Lawa River, whereas Cayodé is located on the Tampok River (Fig. 1). The climate in this area is hot and humid, with an annual average temperature of $27^{\circ} \mathrm{C}$ and an annual relative humidity of $85 \%$. According to the French meteorological services in French Guiana, average rainfall during the two years of the study was $192.7 \mathrm{~mm}$ per month in Maripasoula, with maximum rainfall from April-June. Times of sunset and sunrise were 18:30 h and $06: 30 \mathrm{~h}$, respectively, with little variation during the year. We classified Wayanas' housings as either "modern housing", with walls and relatively well-enclosed or "traditional housing," largely open, without walls or with incomplete walls.

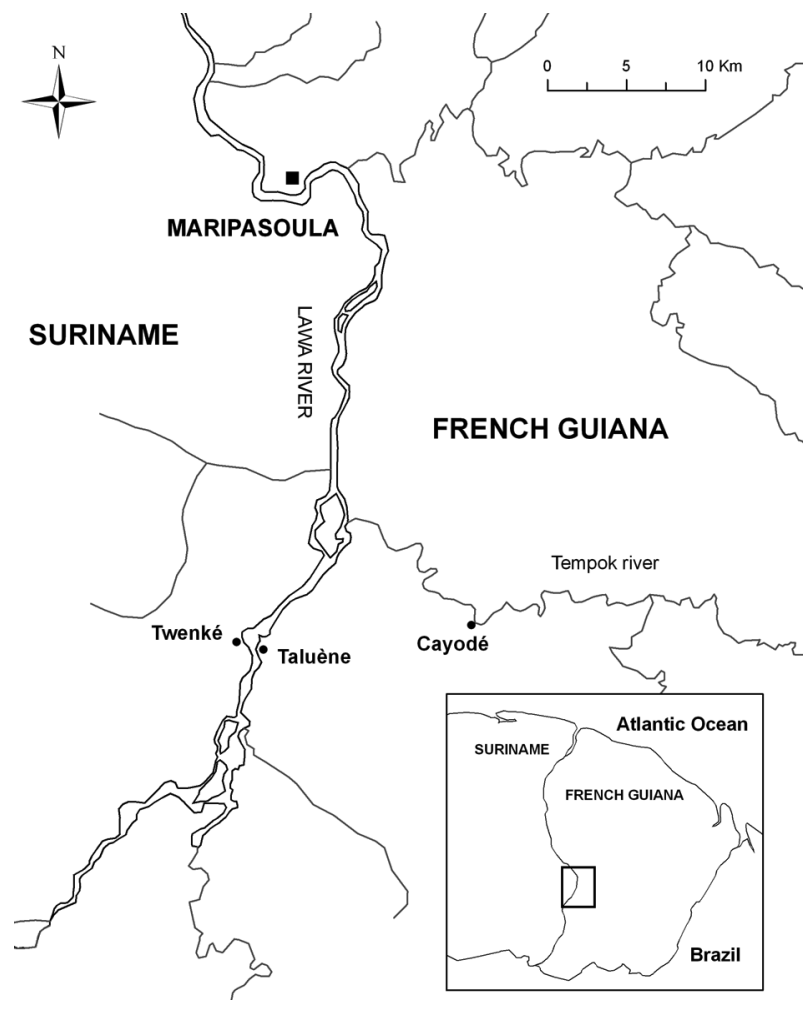

Fig. 1: localization of the three Amerindian villages of Twenké, Taluène and Cayodé (Upper-Maroni, French Guiana).

Field mosquito processing - Standard sampling methods were used: (i) human landing mosquito collections and (ii) resting mosquito collections. In each village, landing catches were performed monthly on two successive nights from 18:30-06:30 $\mathrm{h}$ by a team of two adults legally employed by the Pasteur Institute of French Guiana and working in pairs (the first team working from 18:30-00:30 $\mathrm{h}$ and the second team from 00:30-06:30 h) and rotating every night. The collectors were local residents that have already been exposed to the circulating Plasmodium parasites. They were supervised during the captures by technical and/or scientific staff. Landing collections were performed outdoors from March 2000-February 2002 and completed by mosquito catches inside the two categories of housing described above from May-October 2001, with houses being randomly selected each night. The human landing catches were approved by the Ethical Committee of the Direction de la Santé et du Développement Social of French Guiana, representing the French Ministry of Health in the territory.

In each village, resting mosquito collections consisted of two methods: (i) outdoor checking of pit-shelters or other peridomestic shaded areas carried out during two consecutive mornings each month from JanuaryDecember 2000 and (ii) indoor pyrethroid spray sheet collections performed during two consecutive mornings in April, May and June 2000. 
Individual mosquitoes were labeled according to the catching sites, modes and time of capture. They were sorted by genera, and anopheline mosquitoes were identified morphologically following the keys of Floch \& Abonnenc (1951), Faran (1980), Faran \& Linthicum (1981) and Linthicum (1988). Parous rates of anopheline females were determined by dissecting ovaries and observing the traqueolar skeins (Detinova 1962). At least 10 specimens were dissected per hour when the density of mosquitoes was higher. All mosquitoes were stored individually in numbered vials with desiccant, brought to the Medical Entomology Unit of the Pasteur Institute in Cayenne, French Guiana, and preserved at $-20^{\circ} \mathrm{C}$ until laboratory processing.

Laboratory mosquito processing - The head and thorax of anopheline females were tested by enzymelinked immunosorbent assay (ELISA) for P. falciparum, $P$. vivax (VK210 and VK247 variant epitopes) and $P$. malariae circumsporozoite protein (CSP) detection according to Burkot et al. (1984) and modified by Wirtz et al. $(1987,1992)$.

Data analysis - The human biting rate (HBR) was expressed as the number of female anopheline bites per person per night. The CSP index was calculated as the proportion of mosquitoes found to be positive for CSP. The entomological inoculation rate (EIR) was calculated as the product of the HBR and the CSP index of mosquitoes collected on humans. Vectorial capacity indices (VCI) were estimated according to the formula of Garrett-Jones (1964) for P. falciparum. Considering the lack of previous data concerning An. darlingi, the duration of the gonotrophic cycle was assumed to be three days (Charlwood \& Wilkes 1979) and the human blood index to be 0.5 (Rachou 1958, WHO 1960, Zimmerman et al. 2006). The duration of the sporogonic cycle of $P$. falciparum was assumed to be 11 days, based on the temperatures recorded at the study site (WHO 1975). VCI values were estimated only when at least 10 females were dissected to estimate female parity/survival rates.

\section{RESULTS}

Outdoor human landing mosquito collections From March 2000-February 2002, 236 human-night outdoor captures in the three villages yielded 13,536 mosquitoes, of which 13,309 (98.3\%) were An. darlingi. The other anopheline species identified were $A n$. nuneztovari and Anopheles intermedius. The average An. darlingi HBRs were 41.5, 52.9 and 75.8 bites per human per night in the villages of Twenké, Taluène and Cayodé, respectively (Table I).

$A n$. darlingi was present throughout the year in all three villages, with the most specimens caught in April, May and June. After the rainy season, monthly densities dropped and remained at a lower level for the following months (Fig. 2).

Indoor human landing mosquito collections - From May-October 2001, 72 human-night indoor captures in the three villages yielded 6,013 An. darlingi. No other anopheline species was caught inside houses. The average An. darlingi HBRs were 84.9 and 82.1 bites per human per night in traditional housing and modern housing, respectively. During the same period, the outdoor HBR of An. darlingi was 141.8 bites per human per night (Table II).

Outdoor and indoor resting mosquito collections No anopheline was found in the pit-shelters in the three villages. Furthermore, no anopheline was collected either resting indoors or in shaded areas in the villages in the morning.

\section{TABLE I}

Collecting effort, mosquitoes collected outdoor and Anopheles darlingi human biting rate (HBR) in Twenké, Taluène and Cayodé (Upper-Maroni, French Guiana) from March 2000-February 2002

\begin{tabular}{|c|c|c|c|c|}
\hline Villages & Twenké & Taluène & Cayodé & Global \\
\hline Human-night & 80 & 80 & 76 & 236 \\
\hline Culicidae & 3,439 & 4,310 & 5,787 & 13,536 \\
\hline Anophelinae & 3,326 & 4,234 & 5,768 & 13,328 \\
\hline An. darlingi & 3,319 & 4,228 & 5,762 & 13,309 \\
\hline An. nuneztovari & 0 & 0 & 3 & 3 \\
\hline An. intermedius & 0 & 0 & 1 & 1 \\
\hline An. spp $p^{a}$ & 7 & 6 & 2 & 15 \\
\hline An. darlingi $\mathrm{HBR}$ & 41.5 & 52.9 & 75.8 & 56.4 \\
\hline
\end{tabular}

$a$ : not identified due to the absence of legs and/or wings.

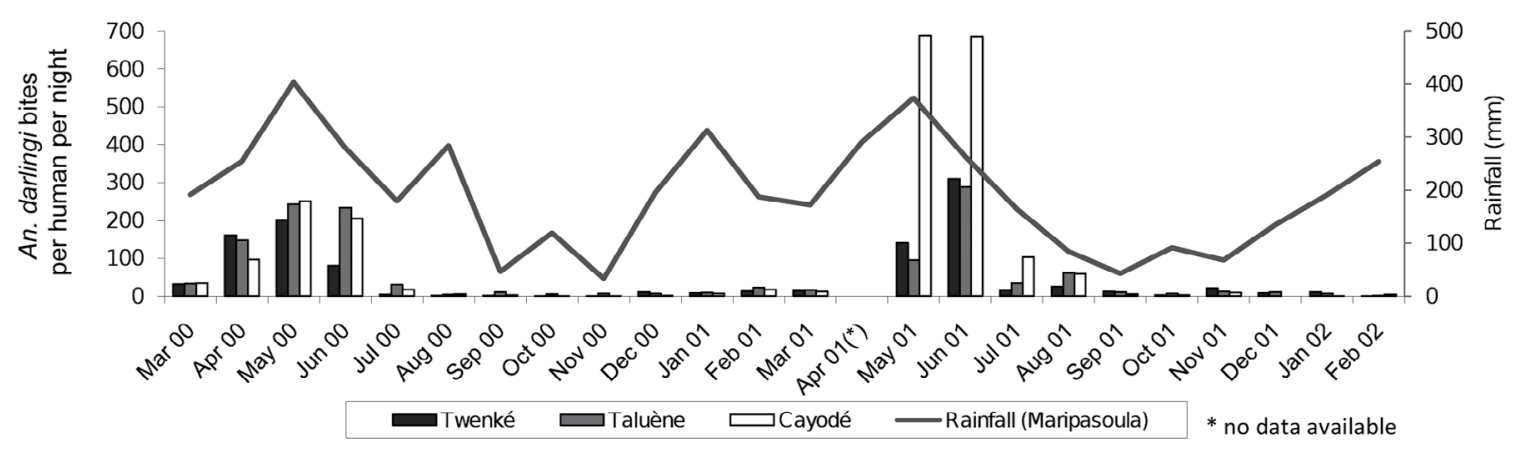

Fig. 2: outdoor Anopheles darlingi human biting rates in Twenké, Taluène and Cayodé in relation with rainfall (Maripasoula) (Upper-Maroni, French Guiana) from March 2000-February 2002. 
Outdoor biting behaviour of An. darlingi - The biting activity cycles were quite similar in the three villages when calculated from the outdoor collections from March 2000 -February 2002. The maximum activity was reached between 21:30-23:30 $\mathrm{h}$ and remained constant throughout the night, with another maximum of activity between 01:30-03:30 h. A slight peak was observed both in Twenké and Cayodé before sunrise (Fig. 3).

Parous rates and VCI - A total of 4,812 An. darlingi females collected outdoors from March 2000-February 2002 have been dissected. The overall parity rates were $0.621,0.661$ and 0.573 in Twenké, Taluène and Cayodé, respectively (Table III). In each village, the monthly values did not vary significantly throughout the season, indicating no evidence for seasonal variability in female survival rates (data not shown). Parity rates were also homogeneous throughout the night, indicating no evidence for nocturnal variability in female survival rates (data not shown). From May-October 2001, 1,137 and 1,149 An. darlingi collected indoors in traditional houses and modern houses, respectively, were dissected. Parous female percentages were respectively $59.4 \%$ and $59.5 \%$. 1,476 An. darlingi collected outdoors were dissected during the same period, and the parous female percentage was $57.7 \%$, showing that there was no difference between the place of collection and the type of house. Mean annual VCI were 7.6, 14.0 and 8.8, respec-

\section{TABLE II}

Anopheles darlingi bites per human per night indoor (traditional and modern housings) in Twenké, Taluène and Cayodé

(Upper-Maroni, French Guiana) from May-October 2001, compared to the outdoor human biting rates observed at the same period

\begin{tabular}{lccrc}
\hline & \multicolumn{3}{c}{ Indoor } & \\
\cline { 2 - 4 } & $\begin{array}{c}\text { Traditional } \\
\text { houses }\end{array}$ & $\begin{array}{c}\text { Modern } \\
\text { houses }\end{array}$ & Total & Outdoor \\
\hline Twenké & 34.1 & 25.3 & 29.7 & 84.7 \\
Taluène & 40.3 & 48.8 & 44.5 & 83.1 \\
Cayodé & 181.4 & 172.3 & 176.3 & 257.7 \\
Global & 84.9 & 82.1 & 83.5 & 141.8 \\
\hline
\end{tabular}

tively, in Twenké, Taluène and Cayodé. Monthly VCI, when calculated, indicated that the malaria transmission risk (VCI $>1$ ) was always present, except during January and September in Cayodé. The highest values (VCI $>10$ ) were observed from April-June in the three villages, and also during January in Taluène and December in Twenké (Fig. 4).

CSP index and EIR - All 13,328 anopheline mosquitoes collected outdoors by human landing collections were processed by ELISA for $P$. falciparum, $P$. vivax VK210 and VK247, and $P$. malariae antigen detection. Fourteen An. darlingi specimens were found positive. The global annual CSP index for this species was $0.15 \%$, $0.14 \%$ and $0.05 \%$, and the annual EIR was $22.8,27.4$ and 14.4 infected bites per human per year in Twenké, Taluène and Cayodé, respectively. All four Plasmodium species and variants were detected. Details are given in Tables IV and V. Positive An. darlingi specimens were found in the three villages during April, June and September. In Taluène, mosquitoes were also found positive in January.

\section{DISCUSSION}

In the Amerindian villages of Twenké, Taluène and Cayodé, An. darlingi was almost the only anopheline mosquito species collected in nocturnal human landing catches from March 2000-February 2002, representing $99.9 \%$ of all anopheline mosquitoes and $98.3 \%$ of all mosquitoes collected. These results confirm similar observations made in the eighties in Bushinenge villages

\section{TABLE III}

Dissecting effort, Anopheles darlingi parous females percentages, survival rates and vectorial capacity index in Twenké, Taluène and Cayodé (Upper-Maroni, French Guiana) from March 2000-February 2002

\begin{tabular}{lcccc}
\hline Villages & Twenké & Taluène & Cayodé Global \\
\hline Number of dissected females & 1,364 & 1,778 & 1,670 & 4,812 \\
Number of parous females & 847 & 1,175 & 957 & 2,979 \\
Parous percentages (\%) & 62.1 & 66.1 & 57.3 & 61.9 \\
Daily survival rates & 0.853 & 0.871 & 0.831 & 0.852 \\
Vectorial capacity index & 7.6 & 14.0 & 8.8 & 10.1
\end{tabular}

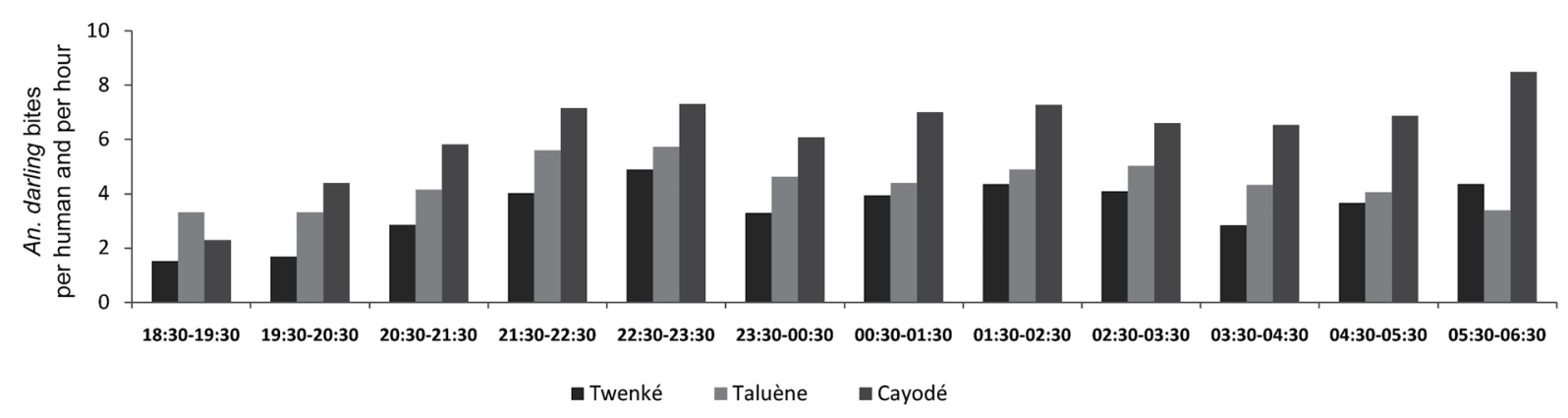

Fig. 3: distribution by hours of Anopheles darlingi bites outdoors in Twenké, Taluène and Cayodé (Upper-Maroni, French Guiana) from March 2000-February 2002. 


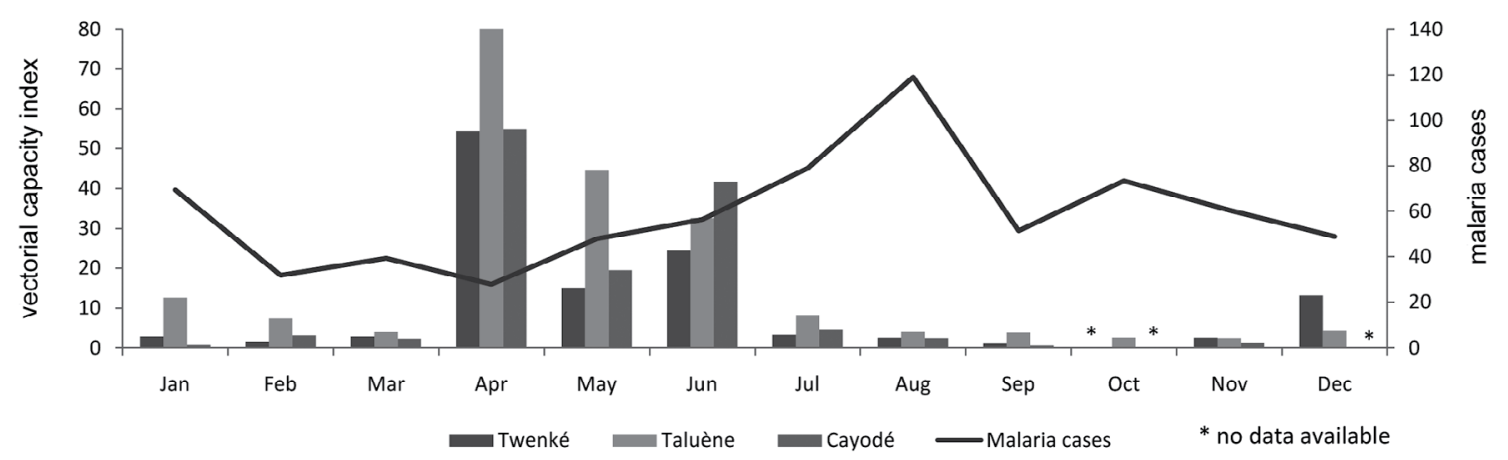

Fig. 4: monthly Anopheles darlingi vectorial capacity index in Twenké, Taluène and Cayodé in relation with monthly malaria cases reported in Maripasoula Health Center (Upper-Maroni, French Guiana) from March 2000-February 2002.

situated downstream from our study sites (Hudson 1984, Rozendaal 1987) and further demonstrate that An. darlin$g i$ is the most anthropophilic mosquito species collected at night in the peridomestic environment of this Amazonian region. Considering all three villages together, the mean An. darlingi HBR was 56.4 bites per human per night, i.e. in one year a person might receive 20,586 $\mathrm{An}$. darlingi bites. Similar observations have been reported recently in some Amerindian villages of the Upper-Orinoco area in Southern Venezuela (Magris et al. 2007b).

Our survey shows a clear seasonal fluctuation of An. darlingi biting densities, the peak of abundance being observed from April-June with an average HBR of 255.5 bites per human per night during this period. The peak of An. darlingi density is reached during the main rainy season, when the village surroundings are flood-

\section{TABLE V}

Annual entomological inoculation rates in Twenké, Taluène and Cayodé (Upper-Maroni, French Guiana) from March 2000-February 2002

\begin{tabular}{lcccr}
\hline Villages & Twenké & Taluène & Cayodé & Global \\
\hline P. falciparum & 4.6 & 4.6 & 9.6 & 6.6 \\
P. vivax & 13.6 & 13.7 & 4.8 & 10.0 \\
P. malariae & 4.6 & 9.1 & 0.0 & 5.0 \\
Global & 22.8 & 27.4 & 14.4 & 21.6 \\
\hline
\end{tabular}

ed. During the dry season, An. darlingi populations are present at lower densities, when the level of the river falls, but may provide secondary larval habitats on its banks. However, An. darlingi biting activity differs in each village, with the situation being very different in Cayodé, which is located close to Twenké and Taluène, but on a different river (Fig. 1). In Cayodé, from May-July 2001, the contact between man and vector was about three times higher than in the other villages, suggesting that larval habitats were exceptionally productive in this locality during this period. Hudson (1984) and Rozendaal (1987) previously showed positive correlations between $A n$. darlingi densities and rainfall and/or river levels in the Maroni valley, and such situations are common in the Amazonian region (Aramburu Guarda et al. 1999, Monteiro de Barros \& Honorio 2007) even if the situation is far from clear in many areas (Soares Gil et al. 2003, Magris et al. 2007b). In our case, considering all three villages together and the rainfall reported during the period of the study, there was a significant positive correlation between $\mathrm{HBR}$ and rainfall $(\mathrm{r}=0.79, \mathrm{p}=0.002)$, with a one month lag, meaning that the abundance of An. darlingi peaked one month after maximum rainfall. A similar analysis also shows a positive correlation between HBR and river levels $(r=0.64$, $\mathrm{p}=0.024)$. Positive correlation between HBR and rainfall and HBR and river levels were also significant considering contemporary data $(r=0.75, p=0.005$ and $r=0.78, p=0.003$, respectively). Seasonal and regional

TABLE IV

Anopheles darlingi circumsporozoite protein index in Twenké, Taluène and Cayodé (Upper-Maroni, French Guiana) from March 2000-February 2002.

\begin{tabular}{lcccr}
\hline & \multicolumn{4}{c}{ An. darlingi circumsporozoite index $\left(\mathrm{CI} 95 \%^{a}\right)$} \\
\cline { 2 - 5 } Villages & Twenké & Taluène & Cayodé & Global \\
\hline P. falciparum & $0.03(0.00-0.17)$ & $0.02(0.00-0.13)$ & $0.03(0.00-0.13)$ & $0.03(0.00-0.08)$ \\
$P$. vivax & $0.09(0.02-0.26)$ & $0.07(0.01-0.21)$ & $0.02(0.00-0.10)$ & $0.05(0.02-0.11)$ \\
$P$. malariae & $0.03(0.00-0.17)$ & $0.05(0.00-0.17)$ & $0.00(0.00-0.06)$ & $0.02(0.00-0.07)$ \\
Global & $0.15(0.05-0.35)$ & $0.14(0.05-0.31)$ & $0.05(0.01-0.15)$ & $0.10(0.06-0.18)$ \\
\hline
\end{tabular}

$a$ : exact binomial method. 
fluctuations in the abundance of An. darlingi reflect local differences in the availability of various types of larval habitats (creeks, strips of flooded forest, river edges and pools in river beds), in relation with both rainfall and river levels. In accordance with Klein \& Lima (1990), we think that the effect of rainfall may be immediately apparent or have a lag time, depending on the type of larval habitat, and thus, the variations in adult abundance of An. darlingi are probably affected by a combination of biotic (quality of aquatic vegetation and fauna) and physical factors, such as temperature and humidity.

An. darlingi indoor HBRs observed in Twenké, Taluène and Cayodé from May- October 2001, compared to outdoor HBRs observed during the same period, showed that the species is endo-exophagous, with a clear predilection for biting outdoors, confirming the results previously obtained in the Maroni valley (Rozendaal 1989). No females were found resting either indoors or outdoors during day, suggesting that An. darlingi is strictly exophilic in this area. Furthermore, no anopheline mosquitoes were found in pit-shelters or shaded areas in the village, indicating that the peridomestic environment in the villages is probably not appropriate for An. darlingi resting sites, with the temperature being too high and/or the humidity rate being too low during the day. On the contrary, there are probably many more suitable resting sites in the rainforest close to the villages. Another hypothesis is that insecticide spraying operations carried out in these villages, even if not regular, might have repellent effects against mosquitoes or may induce changes in their behaviour leading to exophagic and exophilic preferences (Rozendaal et al. 1989). Important geographical variations in resting and biting behaviours of An. darlingi are described in the literature (Roberts et al. 1987, Charlwood 1996, Tadei \& Dutary Thatcher 2000). Indeed, intensive use of insecticides on the inside walls of houses to control An. darlingi is known to cause behavioural changes from endophagy/endophily to exophagy/exophily in the Amazonian basin (Giglioli et al. 1956, Lourenco-de-Oliveira et al. 1989). Because resting and biting behaviours are of considerable importance in terms of vector control implementation, more research is needed concerning this question in the Maroni valley, where it is difficult to assert whether An. darlingi endo/ exophagous and exophilic behaviour is a result of insecticide pressure or is due to unknown ecological reasons.

An. darlingi night-biting activity showed no significant peak in the three villages studied. The maximum number of bites was observed from 21:30-03:30 h, with a slight decrease around midnight. The number of $A n$. darlingi bites recorded at sunset was low, but a slight peak of abundance occurs at sunrise. Great differences in biting activity patterns have been reported throughout the An. darlingi geographic distribution, from very pronounced crepuscular to almost exclusively nocturnal activity (Forattini 1987, Lourenco-de-Oliveira et al. 1989, da Silva-Vasconcelos et al. 2002, Moreno et al. 2007). In the coastal areas of French Guiana, Pajot et al. (1977) showed that An. darlingi presents a biting activity with peaks at dusk, in the middle of the night, and at dawn, but females were also caught in daytime. In Suriname,
Hudson (1984) and later Rozendaal $(1987,1989)$ found a biting peak around midnight. On the Maroni River, these authors showed that the peak number of bites at dusk was essentially due to An. nuneztovari and/or An. oswaldoi, even if An. darlingi was the most represented anopheline species in human landing collections at night around the houses. All these results must be compared with caution because population density causes variations, and differences also exist in habitat typology, location and the period of collection (Elliott 1972, Roberts et al. 1987, Voorham 2002). Variations in biting times will affect the efficiency of personal protection measures, and consequently, the biting rhythms must be documented in every situation in order to define efficient tools for vector control strategies.

The An. darlingi parity rates show an overall mean of 0.619 in the three villages studied. Hudson (1984) also obtained low An. darlingi parity rates in villages situated downstream of our study sites. There was no evidence for any relation between parity rates and seasons. In this area of the Amazonian region, the vectorial capacity seems to be regulated essentially by the mosquito density. Such a phenomenon has already been observed (Charlwood 1980, Moreno et al. 2007), even though the situation could be very different in some other areas (Monteiro de Barros et al. 2007). Low parity rates probably limited malaria transmission in the three villages, except in April, May and June, when densities were at their maximum.

Only An. darlingi specimens were shown to be CSP positive. Due to the predominance of this species in nocturnal human landing catches, we believe that malaria is exclusively transmitted by An. darling i in the peridomestic environment of the villages of this area of the Maroni valley. All Plasmodium species present in the Americas were detected. Such a situation has already been reported recently by Galardo et al. (2007) in the state of Amapá, Northern Brazil, and by Magris et al. (2007b) in the Upper-Orinoco area, Southern Venezuela. In our study, the CSP indices for the three Plasmodium species were not significantly different whatever the village was. The dominance of $P$. vivax and the presence of $P$. malariae in Twenké and Taluène were unexpected results since $P$. falciparum was the cause of $85-90 \%$ of the malaria cases in this area during the period of our study, according to the Maripasoula Health Center. The unexpected CSP index for P. malariae may be due to an underestimation of the real prevalence of this parasite in the human population. P. malariae usually exhibits low parasitaemia and is not easily detected by microscopists. Another hypothesis is supported by the possible existence of the simian parasite P. brasilianum in the Upper-Maroni area (Fandeur et al. 2000). The monoclonal antibodies used in our ELISA to identify $P$. malariae also detect $P$. brasilianum sporozoites (Cochrane et al. 1984). An explanation for the unexpected CSP index for $P$. vivax could be that the Bushinenge people, who are not receptive to $P$. vivax, frequent the health center more often than the Amerindian people. Indeed, the global EIR was 21.6 infected bites per human per year, suggesting that a person might receive one to two infected bites every month. Such an 
EIR appears to be quite low, considering that the UpperMaroni region is one of the most affected malaria areas in South America. Malaria data obtained from the Maripasoula Health Center showed that during our study, malaria cases generally occurred all year long, with an increase in July and a peak in August, at the beginning of the dry season. Therefore, clinical cases follow a parallel curve, with a delay of two to three months after the peak of abundance of An. darlingi. However, statistical analysis showed no significant correlation between HBR and malaria incidence. Furthermore, the clinical cases still remain abundant even when few mosquitoes are caught, and detection of infected mosquitoes both during the rainy season and the dry season indicate that $A n$. darlingi population can maintain malaria transmission rates even when present at low densities in the peridomestic environment. Additionally, malaria transmission may also occur in the forest, implicating selvatic $A n$. darlingi or other anopheline species. In particular, $A n$. nuneztovari has widely been suspected to be an effective malaria vector in Suriname (Panday 1979). Many other additional neotropical species have been proposed as potentially important local or regional vectors based on malaria parasite detection using ELISA or dissecting techniques (Lounibos \& Conn 2000, Povoa et al. 2001, Galardo et al. 2007).

Malaria is still endemic in the Upper-Maroni area, despite of sanitary service commitments for many years. Disease control in the villages of Twenké, Taluène and Cayodé is actually based on curative treatment of suspected and confirmed cases and quarterly house spraying operations with deltamethrin insecticide. Attempts to control malaria transmitted by An. darlingi by spraying houses with residual insecticides have been unsuccessful in many areas for a combination of entomological, environmental and sociological reasons (Rozendaal et al. 1989, Roberts \& Alecrim 1991). The main limiting factor for successful control in Amerindian villages is the difficulty of implementing a strategy adapted to the culture of the local populations. In the villages of Twenké, Taluène and Cayodé, construction practices probably contribute to the persistence of malaria. In the traditional Amerindian houses, residual insecticide house spraying is expected to be ineffective, due in part to repellency. Discontinuing insecticide spraying in houses and instead supporting the use of personal protection and, in particular, promoting the use of insecticide impregnated materials could improve malaria control in such a situation. Amerindian people in the villages of Twenké, Taluène and Cayodé use hammock nets which are generally not impregnated with insecticides, allowing feeding of mosquitoes on people through the net during the night; in other cases, the nets have holes or are inadequately tucked in around the edges. The protective effect would probably be greatly improved by net impregnation with a pyrethroid insecticide. Demonstrations of a reduction in mosquito biting and resting densities in villages where all inhabitants sleep under impregnated nets are numerous in the literature. The use of impregnated nets, coupled with the use of repellents and the early treatment of all fever cases, may be an efficient tool for fighting malaria in this area. The use of long lasting impregnated nets should also render this control method not as costly when compared to regular spraying operations. Zimmerman \& Voorham (1997) pointed out the great difficulty of measuring the impact of insecticide-treated materials on malaria incidence in the context of American malaria vectors, in particular because An. darlingi biting patterns are related to human activities. However, recently, a community-level epidemiological trial, carried out in an indigenous ethnic group of the Amazonian region in Southern Venezuela, showed that lambda-cyhalothrin-treated hammock nets were highly effective against malaria transmitted by An. darlingi (Magris et al. 2007a). It is clear that the use of impregnated mosquito nets or other impregnated materials as a major component of an integrated malaria control program need to be evaluated if implemented in the Amerindian villages of the Upper-Maroni area.

\section{ACKNOWLEDGEMENTS}

To the chief and all the inhabitants of Twenké, Taluène and Cayodé, for giving us warm welcome and especially the collectors in the three villages for their commitment in the present study, to Franck Berger, to his helping in statistical analysis, and to André Spiegel, for reviewing the manuscript.

\section{REFERENCES}

Aramburu Guarda J, Ramal Asayag C, Witzig R 1999. Malaria reemergence in the Peruvian Amazon region. Emerg Infect Dis 5: 209-215.

Burkot TR, Williams JL, Schneider I 1984. Identification of Plasmodium falciparum infected mosquitoes by a double antibody enzymelinked immunosorbent assay. Am J Trop Med Hyg 33: 783-788.

Carme B 2005. Substantial increase of malaria in inland areas of Eastern French Guiana. Trop Med Int Health 10: 154-159.

Carme B, Venturin C 1999. Le paludisme dans les Amériques. Med Trop 59: 298-302.

Charlwood JD 1980. Observations on the bionomics of Anopheles darlingi Root (Diptera: Culicidae) from Brazil. Bull Entomol Res 70: 685-692.

Charlwood JD 1996. Biological variation in Anopheles darlingi Root. Mem Inst Oswaldo Cruz 91: 391-398.

Charlwood JD, Wilkes TJ 1979. Studies on the age composition of samples of Anopheles darlingi (Diptera: Culicidae) in Brazil. Bull Entomol Res 69: 337-342.

Cochet P, Deparis X, Morillon M, Louis FJ 1996. Le paludisme dans le département français de la Guyane. Entre tradition et modernité. Med Trop 56: 185-188.

Cochrane AH, Collins WE, Nussenzweig RS 1984. Monoclonal antibody identifies circumsporozoite protein of Plasmodium malariae and detects a common epitope on Plasmodium brasilianum sporozoites. Infect Immun 45: 592-595.

da Silva-Vasconcelos A, Kato MYN, Mourao EN, de Souza RTL, da L Lacerda RN, Sibajev A, Tsouris P, Póvoa MM, Momen H, RosaFreitas MG 2002. Biting indices, host-seeking activity and natural infection rates of anopheline species in Boa Vista, Roraima, Brazil from 1996 to 1998. Mem Inst Oswaldo Cruz 97: 151-161.

Detinova TS 1962. Age-grouping methods in Diptera of medical importance with special reference to some vectors of malaria. World Health Organization, Monographies Serie 47: p. 13-191. 
Elliott R 1972. The influence of vector behavior on malaria transmission. Am J Trop Med Hyg 21: 755-763.

Esterre P, Cordoliani G, Germanetto P, Robin Y 1990. Epidémiologie du paludisme en Guyane française. Bull Soc Pathol Exot 83: 193-205.

Fandeur T, Volney B, Peneau C, De Thoisy B 2000. Monkey of the rainforest in French Guiana are natural reservoirs for $P$. brasilianum/P. malariae malaria. Parasitology 120: 11-21.

Faran ME 1980. Mosquito studies (Diptera: Culicidae): A revision of the Albimanus Section of the subgenus Nyssorhynchus of Anopheles. Contrib Am Entomol Inst 15: 1-215.

Faran ME, Linthicum KJ 1981. A handbook of the Amazonian species of Anopheles (Nyssorhynchus) (Diptera: Culicidae). Mosq Syst 13: 1-81.

Floch H 1955. La lutte antipaludique en Guyane Française. L’anophélisme. Riv Malariol 24: 57-92.

Floch H, Abonnenc E 1951. Anophèles de la Guyane Française. Arch Inst Pasteur Guyane Terr Inini 236: 1-92.

Forattini OP 1987. Exophilic behavior of Anopheles darlingi Root in a southern region of Brazil. Rev Saude Publica 21: 291-304.

Galardo AKR, Arruda M, D'Almeida Couto AAR, Wirtz R, Lounibos LP, Zimmerman RH 2007. Malaria vector incrimination in three rural riverine villages in the Brazilian Amazon. Am J Trop Med Hyg 76: 461-469.

Garrett-Jones C 1964. Prognosis for interruption of malaria transmission through assessment of the mosquito's vectorial capacity. $\mathrm{Na}$ ture 204: 1173-1175.

Giglioli G 1956. Biological variations in Anopheles darlingi and Anopheles gambiae: their effects on practical malaria control in the Neotropical Region. Bull World Health Organ 15: 461-471.

Hommel D, Bollandard F, Hulin A 1997. Paludisme grave à Plasmodium falciparum. Aspects actuels en zone d'endémie guyanaise. Sem Hop Paris 73: 197-205.

Hudson JE 1984. Anopheles darlingi Root (Diptera: Culicidae) in the Suriname rain forest. Bull Entomol Res 74: 129-142.

Juminer B, Robin Y, Pajot FX, Eutrope R 1981. Physionomie du paludisme en Guyane. Bull Soc Pathol Exot 74: 176-192.

Klein TA, Lima JBP 1990. Seasonal distribution and biting patterns of Anopheles mosquitoes in Costa Marques, Rondonia, Brazil. $J$ Am Mosq Control Assoc 6: 700-707.

Lepelletier L, Gay F, Nadire-Galliot M, Poman JP, Bellony S, Claustre J, Traore BM, Mouchet J 1989. Le paludisme en Guyane française. Situation de l'endémie. Bull Soc Pathol Exot 82: 385-392.

Linthicum KJ 1988. A revision of the Argyritarsis section of the subgenus Nyssorhynchus of Anopheles (Diptera: Culicidae). Mosq Syst 20: 98-271.

Lounibos LP, Conn JE 2000. Malaria vector heterogeneity in South America. Am Entomol 46: 238-249.

Lourenco-de-Oliveira R, Da Gama Guimaraes AE, Arle M, Da Silva TF, Castro MG, Motta MA, Deane LM 1989. Anopheline species, some of their habits and relation to malaria in endemic areas of Rondonia state, Amazon Region of Brazil. Mem Inst Oswaldo Cruz 84: 501-514.

Magris M, Rubio-Palis Y, Alexander N, Ruiz B, Galvan N, Frias D, Blanco M, Lines J 2007a. Community-randomized trial of lambda-cyhalothrin-treated hammock nets for malaria control in Yanomani communities in the Amazon region of Venezuela. Trop Med Int Health 12: 392-403.
Magris M, Rubio-Palis Y, Menares C, Villegas L 2007b. Vector bionomics and malaria transmission in the Upper Orinoco River, Southern Venezuela. Mem Inst Oswaldo Cruz 102: 303-311.

Monteiro de Barros FS, Arruda ME, Vasconcelos SD, LuitgardsMoura JF, Confalonieri U, Rosa-Freitas MG, Tsouris P, LimaCamara TN, Honorio NA 2007. Parity and age composition for Anopheles darlingi Root (Diptera: Culicidae) and Anopheles albitarsis Lynch-Arribalzaga (Diptera: Culicidae) of the Northern Amazon Basin, Brazil. J Vector Ecol 32: 54-68.

Monteiro de Barros FS, Honorio NA 2007. Man biting rate seasonal variation of malaria vectors in Roraima, Brazil. Mem Inst Oswaldo Cruz 102: 299-302.

Moreno JE, Rubio-Palis Y, Paez E, Perez E, Sanchez V 2007. Abundance, biting behaviour and parous rate of anopheline mosquito species in relation to malaria incidence in gold mining areas of Southern Venezuela. Med Vet Entomol 21: 339-349.

Mouchet J, Nadire-Galliot M, Gay F, Poman JP, Lepelletier L, Claustre J, Bellony S 1989. Le paludisme en Guyane. Les caractéristiques des différents foyers et la lutte antipaludique. Bull Soc Pathol Exot 82: 393-405.

Pajot FX, Le Pont F, Molez JF, Degallier N 1977. Agressivité d'Anopheles (Nyssorhynchus) darlingi Root, 1926 (Diptera : Culicidae) en Guyane Française. Cah ORSTOM sér Entomol Méd Parasitol 15: 15-22.

Panday RS 1979. Medical entomological aspects of the malaria problem in Surinam. Sur Med Bull 2: 52-58.

Povoa MM, Wirtz RA, Lacerda RNL, Miles MA, Warhurst D 2001. Malaria vectors in the municipality of Serra do Navio, state of Amapá, Amazon region, Brazil. Mem Inst Oswaldo Cruz 96: 179-184.

Raccurt CP 1997. Paludisme, Anophèles, lutte antipaludique en Guyane Française: entre dogmatisme et discernement. Med Trop 57: 401-406.

Rachou RG 1958. Anofelinos do Brasil: comportamento das espécies vetoras de malaria. Rev Bras Malariol Doenç Trop 10: 145-181.

Roberts DR, Alecrim WD 1991. Behavioural response of Anopheles darlingi to DDT-sprayed house walls in Amazonia. Bull Pan Am Health Organ 25: 210-217.

Roberts DR, Alecrim WD, Tavares AM, Radke MG 1987. The house frequenting, host-seeking and resting behavior of Anopheles darlingi in Southeastern Amazonas, Brazil. J Am Mosq Control Assoc 3: 433-441.

Rozendaal JA 1987. Observations on the biology and behavior of anophelines in the Suriname rainforest with special reference to Anopheles darlingi Root. Cah ORSTOM sér Entomol méd Parasitol 25: 33-43.

Rozendaal JA 1989. Biting and resting behavior of Anopheles darlingi in the Suriname rainforest. J Am Mosq Control Assoc 5: 351-358.

Rozendaal JA 1992. Relations between Anopheles darlingi breeding habitats, rainfall, river level and malaria transmission rates in the rain forest of Suriname. Med Vet Entomol 6: 16-22.

Rozendaal JA, Van Hoof JPM, Voorham J, Oostburg BFJ 1989. Behavioural responses of Anopheles darlingi in Suriname to DDT residues on house walls. J Am Mosq Control Assoc 5: 339-350.

Soares Gil LH, Alves FA, Zieler H, Salcedo JMV, Durlacher RR, Cunha RPA, Tada MS, Camargo LMA, Camargo EP, Perreirada-Silva LH 2003. Seasonal malaria transmission and variation of anopheline density in two distinct endemic areas in Brazilian Amazonia. J Med Entomol 40: 636-641. 
Stroebel M, Lefait JF, Dedet JP 1985. Paludisme à Plasmodium falciparum chez les amérindiens Wayana de Guyane française. Etude séro-épidémiologique d'une population immune. Med Mal Infect 15: $162-164$.

Tadei WP, Dutary TB 2000. Malaria vectors in the Brazilian Amazon: Anopheles of the subgenus Nyssorhynchus. Rev Inst Med Trop Sao Paulo 42: 87-94.

Voorham J 2002. Intra-population plasticity of Anopheles darlingi's (Diptera: Culicidae) biting activity patterns in the state of Amapa, Brazil. Rev Saude Publica 36: 75-80.

WHO - World Health Organization 1960. A study on blood-feeding patterns of anopheles mosquitoes through precipitin tests. Bull World Health Organ 22: 685-720.

WHO - World Health Organization 1975. Manual in practical entomology in malaria. Part II. Methods and techniques, WHO, Geneva, $160 \mathrm{pp}$
Wirtz RA, Burkot TR, Graves PM, Andre RG 1987. Field evaluation of enzyme linked immunosorbent assay for Plasmodium falciparum and Plasmodium vivax sporozoites in mosquitoes (Diptera: Culicidae) from Papua New Guinea. J Med Entomol 24: 433-437.

Wirtz RA, Sattabonkgot J, Hall J, Burkot TR, Rosenberg R 1992. Development and evaluation of an enzyme-linked immunosorbent assay for Plasmodium vivax VK 247 sporozoites. J Med Entomol 29: 854-857.

Zimmerman RH, Galardo AKR, Lounibos LP, Arruda M, Wirtz R 2006. Bloodmeal hosts of anopheles species (Diptera: Culicidae) in a malaria-endemic area of the Brazilian Amazon. J Med Entomol 43: 947-957.

Zimmerman RH, Voorham J 1997. Use of insecticide-impregnated mosquito nets and other impregnated materials for malaria control in the Americas. Rev Panam Salud Publica 2: 18-25. 